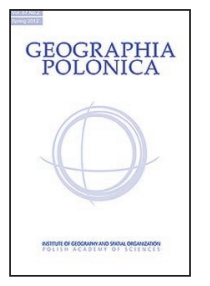

\title{
PERSPECTIVES ON INTERNATIONALISM IN GEOGRAPHY ${ }^{\star}$
}

\author{
Michael E. Meadows $1,2,3$ \\ ${ }^{1}$ Department of Environmental and Geographical Science \\ University of Cape Town \\ Rondebosch 7701: South Africa \\ ${ }^{2}$ Department of Geographical Sciences \\ East China Normal University \\ Shanghai: PR China \\ ${ }^{3}$ College of Geography and Environmental Sciences \\ Zhejiang Normal University \\ Jinhua: PR China \\ e-mail: michael.meadows@uct.ac.za
}

\begin{abstract}
International collaboration in science in general continues to grow and the discipline of Geography is increasingly becoming internationalized. Although there are many benefits to internationalism and, indeed, it is essential if we are to address major global challenges, there is debate as to whether or not existing power relations contribute to cementing unevenness and inequity among the global community of geographers. This is reflected in academic publication practices which clearly advantage particular communities over others. In this essay, I offer some thoughts on the nature of internationalism and its influence on representation in the global geographical community. Important constraints to greater inclusivity are highlighted and the role of the International Geographical Union in potentially offsetting some of the apparent inequities is discussed. The paper concludes with some thoughts as to what is needed if internationalism is to help reduce rather than accentuate such imbalances.
\end{abstract}

\section{Key words}

internationalization - hegemony • scientific publications - International Geographical Union

\section{Introduction}

Given my recent election as President of the International Union it seems both timely and pertinent to offer some reflections on the evolving nature of the international geographical community and, in particular, how internationalism has shaped and continues to influence academic geography.

\footnotetext{
* This article is a modified version of the Polish text,
} which appeared in Przegląd Geograficzny (Meadows, 2019). 
Academic geographers ply their trade within their own institutional, regional and national contexts. But International collaboration in science in general has increased markedly in the recent past, a pattern symbolized in the extremely rapidly growth in number of peer-reviewed publications that are internationally co-authored (Gui, Liu, \& Du, 2019). Indeed, science itself has become progressively globalized through collaboration (Royal Society, 2011) and a lively debate has emerged in academic geography around the nature of multi- (and inter-) disciplinary, multi-institutional and multi-national research networks (Derudder \& Liu, 2016). According to Olechnicka, Ploszaj, and Celińska-Janowicz (2019: 1): "Geography conditions scientific collaboration and how collaboration affects the spatiality of science". While internationalism ${ }^{1}$ may assist geographers in sharing their ideas, developing linkages that increase the quantity and quality of their work, collaborating on larger and more important projects, and even accessing additional research funding, its manifestation is not without problems and has been subject to considerable criticism (Kitchen, 2005; Paasi, 2015). In this paper, I consider emerging trends in scientific collaboration and publications, and explore the role of the International Geographical Union (IGU) in promoting internationalism of our discipline, hopefully in a form that reduces rather than cements inequities in the production and accessibility of geographical research outputs.

There are a number of obvious and substantial advantages to international research collaboration. Indeed, it can be argued that nations should or indeed must cooperate because their collective interests are more important than their differences. As the adage goes: 'a problem shared is a problem halved' and, since all countries face common problems - not least (and not only) in relation to the COVID-19 crisis - it is clear that harnessing scientific talent more broadly should

1 This term is used throughout the article as synonymous with 'internationalisation'. bring about considerable benefits. Indeed, as argued by Zhao, Zhang, Meadows, Liu, Hua, and Fu (2020), the need for collaboration and joint action has never been more germane than it is now as the world grapples with a serious pandemic for the first time in more than a century. There are rewards that manifest in the form of advances in knowledge, improvements in methodology, and at least some evidence that points to elevated citation counts for multi-national authored papers (Mikki, 2017), although such benefits are not always mutually shared (Roussouw \& Ding, 2016) and, in the case of the coronavirus situation, cooperation has been hampered by geopolitical tension (Lee \& Haupt, 2020). The academic community, and geographers are no exception, is becoming increasingly internationalized.

One means of exploring recent trends in internationalism is to consider statistics on academic publication outputs based on bibliographic data. Gui et al. (2019) applied this approach to the Thompson-Reuters Web of Science (WoS) database and deployed social network analysis to investigate recent changes in the structure of international research collaboration. The results point to the globalization of the knowledge economy and, while the authors do not consider geography independently from the other sciences, it is likely that similar trends apply in our discipline. Given the limitation that the WoS database is known to be strongly biased towards Anglo-American journals and English-language publications, the results of the analysis provide fascinating insights as to how the nature of international collaboration has evolved between 2000 and 2015. The most obvious trend is the rapidly expanding number of collaborations globally, and that scientific endeavor is increasingly characterized by partnerships that cross national boundaries. The analysis (Gui et al., 2019) reveals overall marked growth in the number of countries engaging in international collaboration; the number of linkages between countries almost tripled during the fifteen years under consideration. 
Changes in spatial patterns are also evident. For example, in 2000, the network of collaboration was strongly dominated by the 'science superpowers' of the USA, Japan and Europe resulting in bipolar world of science production. However, in particular due to the emergence of East Asia and Australia as increasingly scientifically productive regions, this has gradually evolved into a tri-polar world (Gui et al., 2019; Fig. 1). China's emergence as major player in the global community of science has been especially rapid. Indeed, USA-China partnerships now outnumber all other pairs of countries. The latter pattern may not be fully reflective of Geography, perhaps due to important differences between academic Geography in China and the Anglo-American tradition. Fu, Tian, Liu, and Zhao (2019) describe physical geography in China as the 'cornerstone' of the discipline, which contrasts with the situation in many (or most) other nations, although human geography has undergone significant developments since the reform and opening up in the country after 1978 (Yang \& Chen, 2018). Social scientists in the west, more especially those who aspire to a more critical tradition, may perhaps be more circumspect about engaging in collaborations with researchers in China such that the prominent inclination towards the east that is clear in WoS publication data - mirrored in patterns of scientific mobility (Czaika \& Orazbayev, 2018) - may be less clear in the case of geography.

\section{The need for (and pitfalls of) international collaboration}

The human footprint on earth has undoubtedly pushed various planetary boundaries dangerously close to their limits (Rockström et al., 2009) and placed our own species - along with the millions of others - in peril through the combination of resource overexploitation and the accumulation of products of industrial and agricultural production that now threaten the 'safe operating space' for humanity. Whether or not geologists will ever agree to the formal adoption of the term
'Anthropocene', it is abundantly obvious that humans have profoundly altered earth system processes in such diverse ways as to make extreme and abrupt environmental changes ever more likely; in effect, we have already manifested a 'geology of mankind' (Crutzen, 2002). The fact that the processes involved in such environmental disturbance operate at the full range of spatial scales, from local to global, demands that understanding them - let alone finding ways of managing or resolving them - requires inter-disciplinary, trans-disciplinary and multi-disciplinary approaches that are surely better served through international scientific cooperation.

Nevertheless, there are unintended and less obvious implications of increased levels of internationalism, especially those that arise from unequal power relations among the collaborating parties. The linkages between knowledge and power are such that science (including Geography of course) operates within a core-periphery structure. For example, researchers in the developing world and/ or those in countries where English is not the first language are effectively disadvantaged in a community in which the geographies of international publishing spaces are uneven and one in which the vast majority of geography journals are published and edited in English-speaking countries (Paasi, 2005). English has become increasingly dominant as the language of scientific research publication and this has become a key challenge for social scientists operating in countries beyond the English-speaking world. Thus, internationalism may lead to the intensification of Anglo-American and Anglophonic hegemony (Paasi, 2015) and the observed increased trend in internationalism further intensifies the imbalances. This is an argument also put forward by Meadows, Dietz, \& Vandermotten (2016), who suggest that the hegemony of the global commercial publishing houses is particularly problematic for geography; they go on to provide bibliometric evidence that supports Kitchen's (2005) view that publication practices in the discipline are disruptive and that critical inquiry may even 


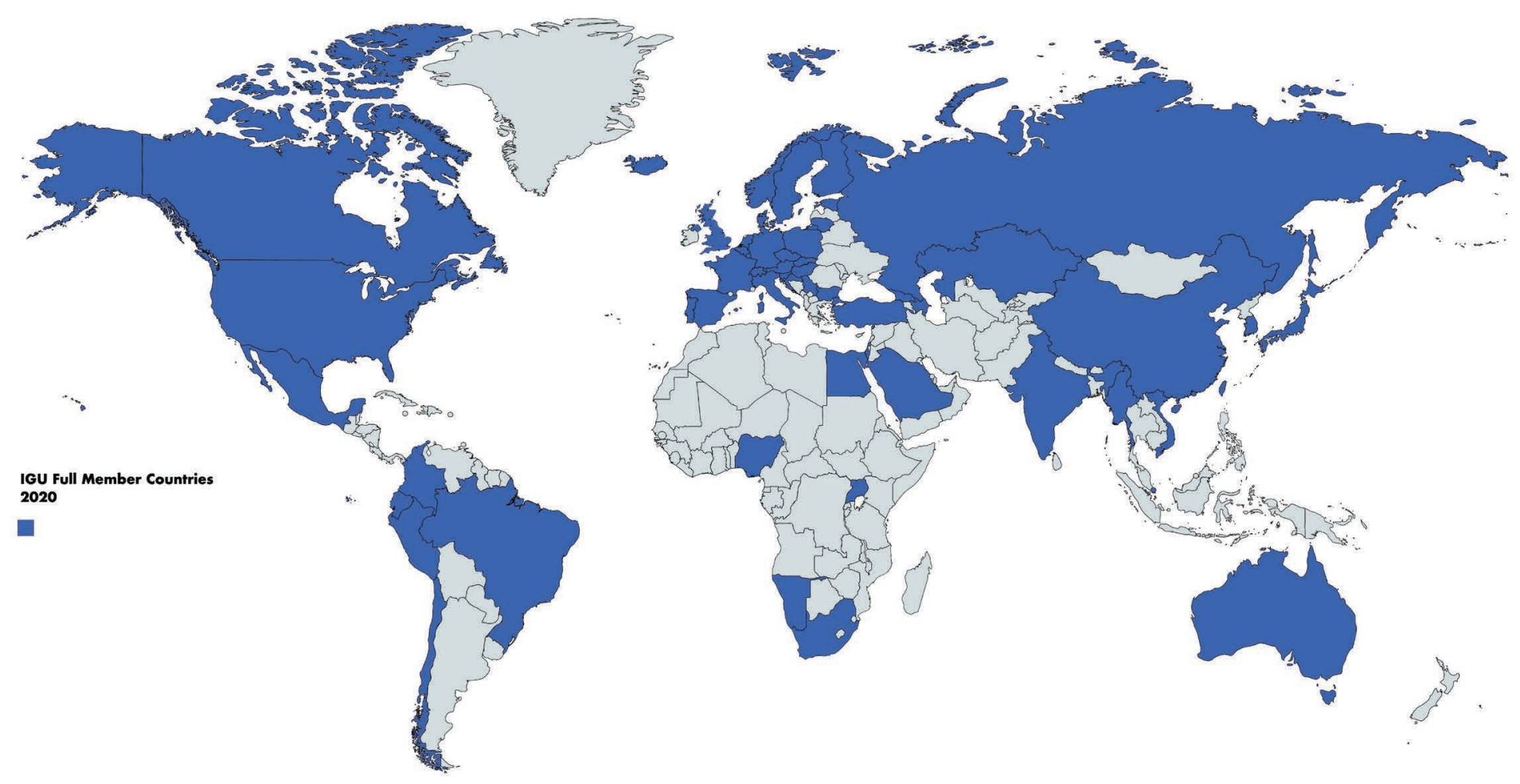

Created with mapchart.net

Figure 1. Distribution of IGU National Committee full membership in 2020

Source: Created with mapchart.net (applies also to Figs. 2 and 3). 
be de-stabilised as a result. The question can be raised as to whether or not academic geographers globally "should continue to accept the substantial language bias imposed by a commercial [WoS] US-based English-focused corporation (Meadows, Dietz, \& Vandermotten, 2016: 3).

But what, if anything, can be done about such problems? In the following section, I explore the historical, current and possible future role of the International Geographical Union in promoting internationalism, and argue that it must try to do so in such a way as to distribute the potential benefits more equitably.

\section{The role of the International Geographical Union}

The International Geographical Union (IGU), formally established in 1922, is an international, non-governmental, professional organization devoted to the global development of the discipline of Geography. The mission of the IGU, as its very name would suggest, is founded on the principle of internationalism. Indeed, the purposes of the IGU are stated as, primarily, to promote Geography through initiating and coordinating geographical research and teaching in all countries of the world (author's italics; see: http:// www.igu-online.org/). Geographers first convened under the umbrella of an International Geographical Congress in Antwerp, Belgium, in 1871 with representation from some 20 countries (Martin, 1996), the vast majority of whom were non-academics (mainly military officials and civil servants). Congresses were held every three or four years thereafter until 2019 when, following the ratification of the Treaty of Versailles that heralded the formal end of the First World War. Article 282 of the treaty made provision for the establishment of an International Research Council (IRC) whose principal object was to establish international 'Unions' among the different sciences (Hinks, 1922). Membership of such unions was envisaged to be national, rather than individual, with all member countries represented by a National Committee for each scientific discipline in question. The IGU was duly ratified and was formally admitted under the auspices of the International Research Council at its General Assembly on July 29th 1922, with an Executive Committee comprised of Prince Napoleon Bonaparte (France) as President, Sir Charles Close (United Kingdom) as Secretary-General, General Vacchelli (Italy) as First Vice-President, and three other Vice-Presidents from Japan, Spain and Belgium (Martin, 1996). The manner of IGU establishment immediately set the tone of internationalism and, by 1925, there were 14 member states ${ }^{2}$, although participation was restricted to national members of the IRC, which meant that nations such as Germany, Austria, Hungary and Turkey were initially excluded. This restriction eventually led (in 1931) to the IGU disassociating from the IRC, and affiliating instead with the International Council of Scientific Unions (ICSU) which had no such limitations (Martin, 1996). While the fundamental structure of the IGU executive has remained largely the same, it has expanded to eight Vice-Presidents, and its strongly international character has been further reinforced. The current executive is drawn from Japan, India, Australia, France, Spain, Italy, Turkey, Switzerland, China, the United States and South Africa, so the eurocentric essence of the original leadership is now at least partially tempered. Since its establishment, nationals of 16 different countries have been elected as IGU President. While full national membership of the IGU is widely distributed and stands at more than 60 countries drawn from all regions of the globe (Fig. 1), the absence of members from many African and middle eastern countries is glaring.

The IGU's original aim to be a genuinely international body remains to this day, whereby its elected executive, Commission and Task Force structure, and the nature of its activities are all focused on widening the geographical footprint. For example, the current IGU

\footnotetext{
2 Poland was accepted as a full member in 1924.
} 
Statutes (item VI D) (https://igu-online. org/organization/statutes/) stipulate that: 'A Commission shall consist of a Chair and a Steering Committee normally consisting of not more than ten other members...Normally, there shall not be more than one member from any one adhering country' (author's italics). This ensures as wide a national representation as possible. The 44 Commission and Task Force Chairs are currently drawn from no less than 30 different countries (Fig. 2) but a very strong northern hemisphere dominance is apparent, with Africa, middle eastern and Latin American countries markedly underrepresented. Each of the Commissions and Task Forces have steering committees of up to 10 members, and this extends national representation within formal IGU bodies to 80 countries (Fig. 3). In terms of its activities, major IGU events such as Congresses and Regional Conferences, have now been hosted by more than 20 countries on every continent. The upcoming 34th International Geographical Congress in Istanbul, Turkey, (August 2021) has abstract submissions from delegates of more than 100 countries (Chair of the Local Organizing Committee, personal communication). The IGU further facilitates the mobility of younger colleagues, and those from developing countries, through its travel grant scheme. The Young and Early Career Geographers Task Force was established in 2016 to promote career development for early career geographers, stimulate international and inter-generational research conversations between geographers, and elevate the achievements of early career geographers around the world (http:// igu.younggeographers.org/) None of this, of course, can actually guarantee more effective international collaboration. For example, despite their being 90 countries represented at the 2013 annual meeting of the AAG, the organization remains "(...) inward looking in the sense that intra-national ties are at least twice more likely to be realized than international ties" (Derudder \& Liu, 2016). In short, bodies such as the IGU may strive for internationalism, but much work remains to be done ${ }^{3}$.

Thus, the occurrence or even prominence of internationalism within the IGU community in terms of its structures and activities does not automatically offset the hegemony of scientific endeavour that prevails globally and reinforced by the dominance of English as the lingua franca of academic research (Paasi, 2015). However, the sheer diversity of IGU membership and the geographical spread of locations chosen for its congresses, regional, thematic and Commission and Task Force conferences surely assist in 'spreading the news'. The IGU aims to foster research contributions from a wider range of geographical communities than would otherwise exist even in the larger 'national' bodies such as the annual meetings of the American Association of Geographers (AAG) and the Royal Geographical Society (RGS) whose structures and events may be more geographically exclusive than IGU Congresses. The IGU has established Commissions that focus explicitly on continents or regions of the world traditionally regarded as more peripheral to the research enterprise, in particular the Commissions on Latin American Studies, and on African Studies. There are ongoing attempts to communicate in languages other than English, for example all official conference literature, such as the call for abstracts, is also made available in French (at least), and the IGU publicity brochure is available in English, French, Spanish and Portuguese versions. Most of the core information on the IGU website (http://www.igu-online.org) is made available in French and Spanish versions.

Peer-reviewed publications are the de facto unit of currency for research productivity in the discipline of Geography and are often the main (or even only) means by which performance of most University academics is assessed. Anglo-American journals dominate

3 This is also the case in terms of gender imbalance: 4 of the 11 current (2020-22) IGU Executive Committee are women, only 15 of the 44 Commission and Task Force have female chairs and two thirds of the more than 450 steering committee members are men. 


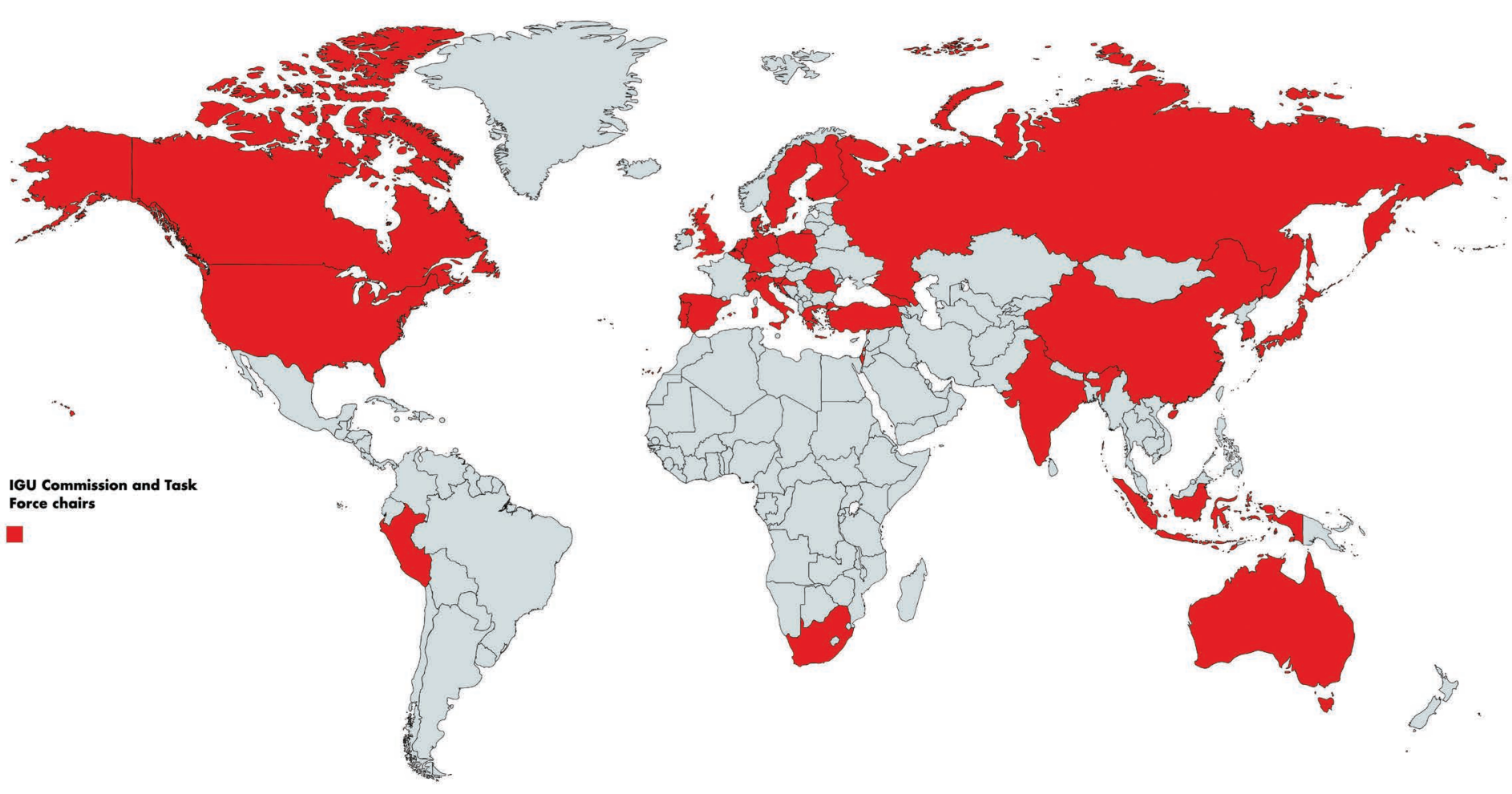

Created with mapchartnet

Figure 2. Distribution of domicile country of the 2020 IGU Commission and Task Force chairpersons 


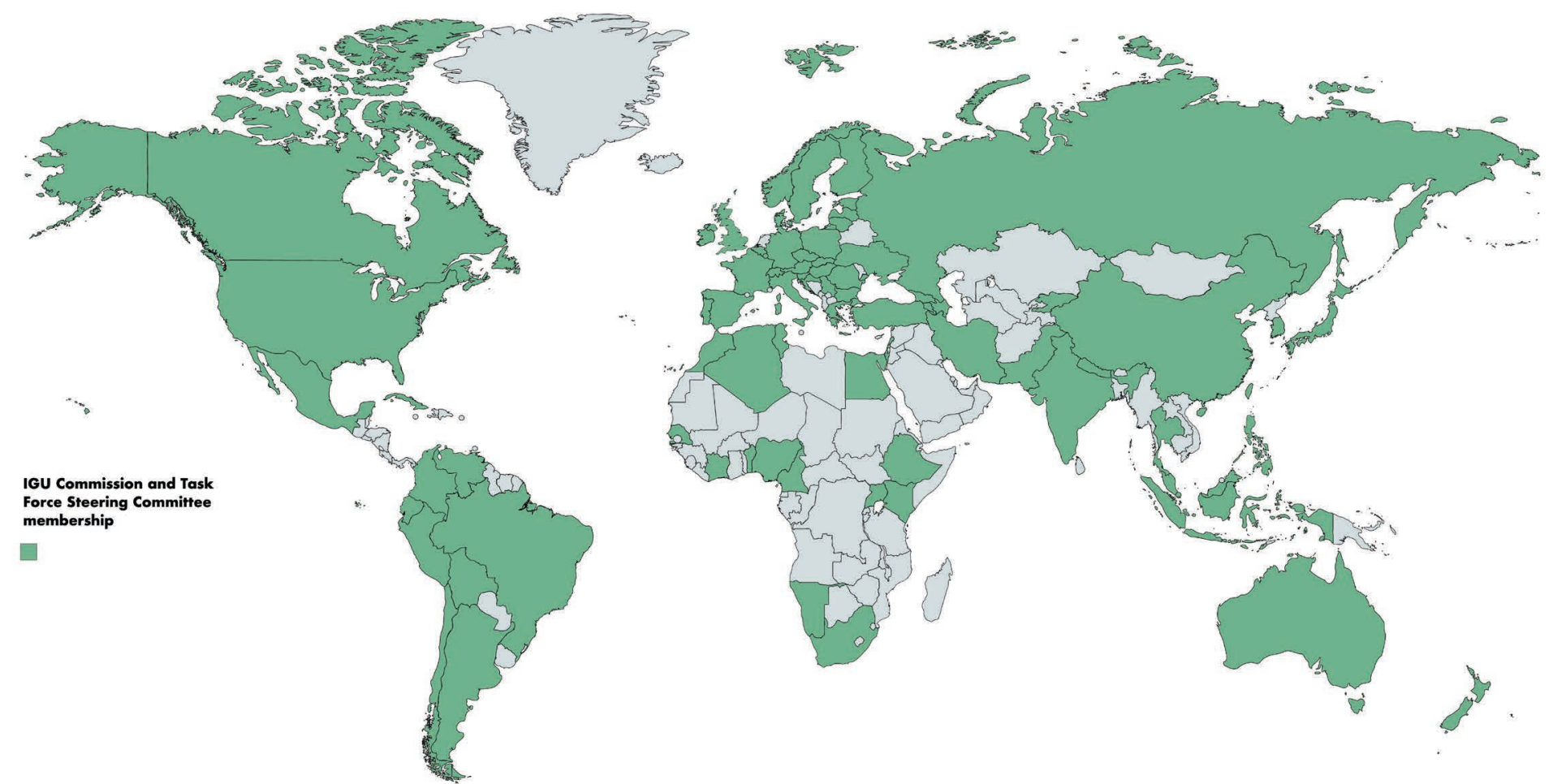

Figure 3. Distribution of domicile country of the 2020 IGU Commission and Task Force steering committee members 
the publishing space in science in general and in human geography in particular (Paasi, 2005) and "English language is not only the key medium in [the] standardization [of publication practices] but increasingly also a major source of the standards" (Paasi, 2015: 259). However, Paasi goes on question whether there is anything wrong with geographers from diverse countries submitting their work to the Anglophone leading international journals? At the individual level, I would suggest that the answer to this question may be 'nothing', but, like Paasi, I agree that publication patterns remain a problem for Geography as a discipline and, especially for an organization like the IGU which aims for increasing internationalism, one that needs to be addressed. Following sessions convened by Christian Vandermotten and Ton Dietz at the IGU meetings in Cologne (2012), Kyoto (2013) and Krakow (2014), the IGU executive took the decision to establish a more inclusive database of geography, and geographyrelated journals and make this available via its website. This was effected through 'crowdsourcing' information supplied by contacts from the IGU national committee distribution list with the intention that this would sample a much wider array of journals and include many that are published in languages other than English; hence, the IGU 'journals project' was initiated (https://igu-online.org/journalsproject/). Meadows et al. (2016) examined patterns in the ranking of geographical journals in the major global databases (WoS, Scopus) and compared these with the IGU journals project listing. The results highlight the many shortcomings of conventional journal ranking systems including, among others, marked linguistic bias, the lack of representation of books and chapters in books, and the geographical unevenness of so-called accredited journals, all of which are especially problematic for geographers, especially human geographers. The journals project database continues to develop and, while it does not necessarily directly address hegemonic practices in the corporate world of academic publishing, it at least makes accessible journals from smaller countries that may publish their journals in languages used only by a relatively small research or teaching community, including Geographia Polonica.

\section{Promoting international collaboration in Geography: What is still needed?}

If internationalism is to flourish in the discipline, Anglo-American dominance needs to be challenged and academic geography must strive to be as globally representative as possible. There is more to this than simply suggesting that geographers from a much wider community should be given an opportunity to contribute, for the current system entrenches exclusion (Cochrane \& Thompson, 2018) and, as Paasi (2015: 260) notes, "a balanced and active exchange of ideas provides more benefit for science than unidirectional flows". This becomes even more important against the background of global environmental change and in the need for geographers especially (Liverman, 2018) to embrace the United Nations Sustainable Development Goals (SDGs) which have the objective of 'leaving no one behind'.

Several challenges are evident. Firstly, scientific endeavour needs to be advanced across all nations to reduce imbalances in capacity and enable the participation of a more complete global community to address the key global challenges that are highlighted in the SDGs. In a digital world in which so-called 'fake news' is so easily disseminated through the media, not least social media, we must endeavour in our research to ensure that decisions made by key role players at all political levels are evidencebased. "Providing the evidence to support decision-making that is equitable and inclusive necessitates critical reflection (...) along with innovation and creativity in how the research community can address gaps and support the more inclusive SDG agenda" (Cochrane \& Thompson, 2018). This is not an easy task, for the very credibility of science and scientists is frequently questioned at the highest level of decision-making, and by the most powerful 
politicians in the world (a case in point would be Donald Trump's description of climate scientists as 'prophets of doom' at the 2020 World Economic Forum: https://www.bbc. co.uk/news/world-europe-51189430).

The free and unfettered availability of published scientific information and of scientific data is also essential if we are to address imbalances and inequities in the academic world. This too is easier said than done, although a wide range of geospatial data products are becoming more accessible through platforms such as Google Earth Engine (https://earthengine.google.com/). On the other hand, scientific journal subscriptions, under the auspices of just a handful of very powerful global publishing houses, are increasingly unaffordable in many countries, especially those of the developing world. The Open Access (author pays) model results in published papers being freely and more widely available to the global community, but publication charges levied to authors are often excessive so that the system actually entrenches the spatially uneven production of research outputs. In some countries, scientific information obtained via the internet is subject to strong controls, restricted access and even censorship; clearly such a situation negates the very concept of internationalism. Freedom of movement and exchange of ideas among scientists, along with improved opportunities for international exchanges and conference attendance, are essential elements of internationalism. Geographers in the developed world are more likely to be able to avail themselves of such opportunities, while there are crippling funding constraints facing researchers in many countries and high costs of transport and conference attendance certainly contributes to maintaining the status quo regarding academic power relations. Visa constrictions are often especially challenging for researchers from poorer countries (Czaika \& Neumayer, 2017). From personal experience as former Treasurer of the IGU, I know of many instances where delegates who have been awarded travel grants to attend our conferences have been unable to do so due to visa applications being rejected. Purely from an IGU perspective, Figure 2 here reveals that encouraging more geographers from the global south, especially in Africa, to be engaged as chairs or steering committee members of its Commissions and Task Forces would seem to be a necessity.

In summary, then, while the goal of internationalism is a noble one, there is a danger that it may serve to deepen, rather than alleviate, the disparities and inequities that persist in the global academy. The IGU can certainly contribute to ongoing efforts to iron out these imbalances; this is essential to ensure that the potential benefits of internationalism are more widely and more equitably shared.

\section{Editors' note:}

Unless otherwise stated, the sources of tables and figures are the authors', on the basis of their own research.

\section{References}

Cochrane, L., Thompson, A. (2018). The Geography of Development Studies: leaving no one behind. Forum for Development Studies 45(1), 167-175. https://doi.org/10.1080/08039410.2017.1345786

Crutzen, P.J. (2002). Geology of mankind: The Anthropocene. Nature, 415(23). https://doi.org/10.1038/415023a

Czaika, M., Neumayer, E. (2017). Visa restrictions and economic globalization. Applied Geography, 84, 75-82. https://doi.org/10.1016/j.apgeog.2017.04.011

Czaika, M., Orazbayev, S. (2018). The globalization of scientific mobility, 1970 to 2014. Applied Geography, 96, 1-10. https://doi.org/10.1016/j.apgeog.2018.04.017 
Derudder, B., Liu, X. (2016). How international is the annual meeting of the Association of American Geographers? A social network analysis perspective. Environment and Planning A: Economy and Space, 48(2), 309-349. https://doi.org/10.1177\%2F0308518X15611892

Fu, B., Tian, T., Liu, Y., Zhao, W. (2019). New developments and perspectives in physical geography in China. China Geographical Sciences, 29(3), 363-371. https://doi.org/10.1007/s11769-019-1038-y

Gui, Q., Liu, C., Du, D. (2019). Globalization of science and international scientific collaboration: A network perspective. Geoforum, 105, 1-12. https://doi.org/10.1016/j.geoforum.2019.06.017

Hinks, A.R. (1922). The International Geographical Union. Geographical Journal, 60(4), 291-294.

Kitchin, R. (2005). Commentary: Disrupting and destabilizing Anglo-American and English language hegemony in geography. Social and Cultural Geography, 6, 1-15.

https://doi.org/10.1080/1464936052000335937

Lee, J.J., Haupt, J.P. (2020). International research collaborations on COVID-19 amidst geopolitical tensions with China. Research Square. https://doi.org/10.21203/rs.3.rs-37599/v1

Liverman, D.M. (2018). Geographic perspectives on development goals: Constructive engagements and critical perspectives on the MDGs and the SDGs. Dialogues in Human Geography, 8(2), 168-185. https://doi.org/10.1177\%2F2043820618780787

Martin, G. (1996). One hundred and twenty five years of Geographical Congresses and the formation of the International Geographical Union. Or, from Antwerp to The Hague. IGU Bulletin, 46, 5-26.

Meadows, M.E., Dietz, T., Vandermotten, C. (2016). A perspective on problems and prospects for academic publishing in Geography. Geo, 3(1), 1-7. https://doi.org/10.1002/geo2.16

Meadows, E.M. (2019). Perspektywy internacjonalizacji badań i współpracy w naukach geograficznych. In Wiśniewski, R., Regulska, E. (Eds.), /Tradycja i współczesność geografii w Polsce/ (pp. 85-94). Warszawa: Instytut Geografii i Przestrzennego Zagospodarowania im. S. Leszczyckiego PAN.

Mikki, S. (2017). Scholarly publications beyond pay-walls: increased citation advantage for open publishing. Scientometrics, 113, 1529-1538. https://doi.org/10.1007/s11192-017-2554-0

Olechnicka, A., Ploszaj, A., Celińska-Janowicz, D. (2019). The geography of scientific collaboration. London: Routledge. https://doi.org/10.4324/9781315471938-7

Paasi, A. (2005). Globalisation, academic capitalism, and the uneven geographies of international journal publishing spaces. Environment and Planning A: Economy and Space, 37(5), 769-789. https://doi.org/10.1068/a3769

Paasi, A. (2015). "Hot spots, dark-side dots, tin pots": The uneven internationalism of the global academic market. In P. Meusburger, D. Gregory, L. Suarsana (Eds.), Geographies of knowledge and power (pp. 247-262). Dordrecht, The Netherlands: Springer. https://doi.org/10.1007/978-94-017-9960-7_12

Rockström, J., Steffen, W.L., Noone, K., Persson, Å., Chapin III, F.S., Lambin, E., ... Nykvist, B. (2009). Planetary boundaries: exploring the safe operating space for humanity. Ecology and Society 14(2), 32.

Roussou, R., Ding, J. (2016). Does international collaboration yield a higher citation potential for US scientists publishing in highly visible interdisciplinary journals? Journal of the Association of Information Science and Technology, 67(4), 1009-1013. https://doi.org/10.1002/asi.23565

Royal Society. (2011). Knowledge, networks and nations: Global scientific collaboration in the 21st century. London: The Royal Society.

Yang, R., Chen, Y. (2018). Change in key research area and prospect of Chinese rural geography. Progress in Geography, 37(5), 601-616.

Zhao, W., Zhang, J., Meadows, M.E., Liu, Y., Hua, T., Fu, B. (2020). A systematic approach is needed to contain COVID-19 globally: China's experiences for the world. Science Bulletin, 65, 876-878. https://dx.doi.org/10.1016\%2Fj.scib.2020.03.024 
